\title{
FATHOM
}

\section{Observing Objects as Mutability and Meaning in Thomas Hardy's Human Shows (1925)}

Les objets dans Human Shows de Thomas Hardy: sens et mutabilité

\section{Adrian Grafe}

\section{(2) OpenEdition \\ 1 Journals}

\section{Electronic version}

URL: http://journals.openedition.org/fathom/1100

DOI: $10.4000 /$ fathom. 1100

ISSN: 2270-6798

\section{Publisher}

Association française sur les études sur Thomas Hardy

\section{Electronic reference}

Adrian Grafe, « Observing Objects as Mutability and Meaning in Thomas Hardy's Human Shows (1925) », FATHOM [Online], 6 | 2019, Online since 01 October 2019, connection on 14 October 2019. URL : http://journals.openedition.org/fathom/1100; DOI : 10.4000/fathom.1100

This text was automatically generated on 14 October 2019 


\title{
Observing Objects as Mutability and Meaning in Thomas Hardy's Human Shows (1925)
}

\author{
Les objets dans Human Shows de Thomas Hardy: sens et mutabilité
}

Adrian Grafe

1 Thomas Hardy (1840-1928) lived to the age of eighty-seven, a good innings by anyone's standards but especially good for the time, particularly among writers. Henry James (1843-1916) was born shortly after Hardy and died twelve years before him. Joseph Conrad (1857-1924) was born seventeen years after Hardy and died four years before him. Not the least idiosyncrasy of his career is that Hardy's longevity enabled him to have two writing lives - following upon his occupation as a novelist. Devoting himself full time to poetry - even though he had always written it - literally gave him a new lease of life, and a second, but by no means secondary, writing life. Poetry, like his first wife, Emma Gifford, was always his first love: during her lifetime she was as it were his virtual muse, morphing into his real one when in the "Poems of 1912-13", he wrote the poems that lay dormant during his first marriage, waiting to be written while he toiled at his livelihood as a prose writer ${ }^{1}$. His first writing life lasted for twenty-seven years. It began with The Poor Man and the Lady (1868), rejected by Macmillan, and ended with Jude the Obscure, published in 1895. Wessex Poems appeared in 1898 and Hardy regularly published poetry over his thirty remaining years. Why is it then that James Gibson's Literary Life (1996) devotes far more space to the novelist than the poet? The fact that Gibson devotes twelve pages to The Poor Man and the Lady, of which no manuscript subsists, and just three to Human Shows, speaks volumes for current critical attitudes to poetry, and Hardy's in particular, even coming from the editor of that poetry. R. G. Cox's Thomas Hardy: The Critical Heritage (1970) devotes three quarters of its space to the novels. After covering reviews of the first three volumes of Hardy's twelve volumes of verse, Cox seems to get fed up with his whole editorial enterprise and doesn't even bother mentioning Human Shows. Surely this misrepresents the author, whose poems were the part of his literary production that meant most to him. Perhaps the best 
account of Human Shows is that of Rosemarie Morgan, who both reads the poems closely and assesses the collection as a whole. She relevantly notes that in the collection "significance is given to what seems insignificant" (Morgan 184): the discrepancy or gap between being and seeming lies, as its title suggests, at the thematic heart of the volume, and Morgan's remark is especially true of the treatment of objects therein, including the objectivisation of what is not originally an object ${ }^{2}$.

2 Hardy's feeling for objects - one might say, borrowing a term of Chesterton's (quoted just below) which Hardy approved, his "sense of" the object - is attested to in countless places in his writings in prose and verse. To take but two examples, one his own, the second copied from elsewhere: "An object or mark raised or made by man on a scene is worth ten times any such formed by unconscious Nature. Hence clouds, mists, and mountains are unimportant beside the wear on a threshold, or the print of a hand" (quoted in Armstrong 332; Hardy's note dates from 1877). The demonstrative pronoun group "any such" refers to the "object or mark" previously mentioned. The sentence seems to be anti-Romantic, denoting a search for meaning within the realm of human activity alone, rather than in response to, or communication with, "Nature". But Hardy in 1877 was not primarily a poet, and some poems in Human Shows (we take "Why Do I?" as an example in the concluding section of this essay) either conceal meaning or deal in ambivalence, a "mark" of which is Hardy's contorted syntax. He copied into his notebook a passage from Chesterton's study of Browning:

The sense of the terrible importance of detail was a sense wh. may be $s^{\mathrm{d}}$. to have possessed Browning in the emphatic manner of a demoniac possession...Any room that he was sitting in glared at him with innumerable eyes \& mouths gaping with a story... If he looked at a porcelain vase or an old hat, a cabbage, or a puppy at play, each began to be bewitched...the vase to send up a smoke of thoughts \& shapes; the hat to produce souls as a conjuror's hat produces rabbits; the cabbage to swell \& overshadow the earth like the Tr. of Knowge; and the puppy to go off along the road to the end of the world -" [This is true of all poets-not especially of Browning] (Björk 152-153)

3 Hardy twice underlines the last four words in order to emphasise what he finds in Chesterton's description of Browning. Hence what is intrinsic to a poet is on the one hand his sense of detail, and on the other the element of possession which Chesterton says would overcome both Browning as he encountered objects and account for the latter's "bewitched" quality when they met his gaze. This is perhaps a post-Romantic version of Keatsian negative capability - "the poet is the most unpoetical of any thing in existence" (Keats 119) - since it suggests that there is no hierarchy of subjects in poetry: no subject is worthier of treatment in a poem than any other, partly because, in poetry, subject-matter is in any case not of the essence, but mainly because all things to a poet are equally worthy of interest when it comes to making a poem. This argument would in itself explain the plethora of objects, domestic and outdoor, in Hardy's writing: what Hardy sees and feels in the phenomena around him is life or, to use Chesterton's word, soul, even ${ }^{3}$. Thus the poet's, and in particular Hardy's, feeling for the aliveness of the world, an aliveness that is, to some extent, created by the poet, can be related to Winnicott's notion of the "aliveness and behaviour of the external object" (Winnicott 413) that is available to the child and that will later affect his relationship with religion, the arts, and scientific creativity ${ }^{4}$.

One could also take the question of objects in Hardy's poetry, at least in Human Shows, as a purely poetic one. In this respect, he tallies, as Michael Alexander pointed out, with 
Pound: "Hardy [...] conformed before it was articulated to Pound's demand for 'direct treatment of the object' - the 'natural object' which, in Pound's view, was 'the proper and perfect symbol"' (Alexander 52). Nevertheless the "natural object" is not always symbolic in Hardy's poetry, just as the cows in Hardy's poem "Bags of Meat" are primarily themselves (though the way in which human beings treat or mistreat them may make them into metonymies for the natural world).

We encounter the Hardy of Human Shows, published three years before the poet's death, raging against the dying of the light - indeed, the light is hardly dying at all. One might argue that the one hundred and fifty-one poems that make up Human Shows, Hardy's penultimate poetry volume and the last to be published in his lifetime, show his poetic imagination to be working at its most powerful, and that his treatment of objects in the collection bears this out. Incidentally, unlike Late Lyrics and Earlier (1922) before it, and Winter Words in Various Moods and Metres (1928) after it, no prose note prefaces the collection of poems, as though Hardy felt that anything he had to say there lay within the poems alone and perhaps the excessively descriptive full title, Human Shows, Far Phantasies, Songs, and Trifles, in itself an iambic, and lightly tripping, pentameter line. It is a collection that redounds not only in shows and fantasies but in "Premonitions", "forebodings" ("The Lady of Forebodings"), "visions" ("Discouragement"), and "phantoms" ("Song to an Old Burden"). In this context full of abstract emotion, objects serve both as metaphors for the reality of such emotion and as realia linking the poet to the phenomenal world so beloved of Hardy. Hence, we take the term "objects" for the purposes of argument, as first of all, not only what David Trotter calls "functional objects", but also the various components of the phenomenal world, some man-made, others natural, occurring in the poems. Some of the "phantasies", moreover, as we'll see below, are not as "far", in place at least, as Hardy's collection title suggests.

Hardy's attentiveness to objects in his poems reflects his attentiveness to, and care for, language: each object is meticulously named and has its own place in the poem. Are objects in Hardy's poetry a source of wonder? If they are, they would function as an antidote to the poet's philosophical pessimism. Hardy's perspective upon objects is to situate them within deep time, the time of geology and archaeology. This lends a density which grants them significance that goes beyond the object's immediacy. Objects have a resurrectionary power in Hardy's poetry, capable of reviving the past within the present and bringing something new to it. Hence Robert Gittings's view, that the poems in Human Shows are "thin", warrants some qualification: they are not necessarily or not all without substance, and the impression of thinness may in any case conceivably be intended, even if it is true that some poems satisfy more than others ${ }^{5}$. Hardy's specific focus on objects can be seen as an aesthetic and even political choice, an option for, and celebration of, the everyday, as opposed to the tawdry or the fashionable - the showy, in fact. If a poetics of wonder is to be grounded anywhere, it is to be grounded in the serendipity of commonness and dailiness.

7 In Human Shows, Hardy's approach to objects - as with any subject he tackled - is far from systematic or univocal. This essay therefore aims at showing how Hardy exhibits a variety of perspectives on the poetic object. On a simple level, Hardy applies the techniques of personification and apostrophe to "To a Sea-Cliff" (Hardy 793-794), but goes far beyond them. If the sea-cliff can be considered as an object, then it is clear that its role in the poem is central, not descriptive or circumstantial, endowed with the indeterminate ontology that, attributing a partial sense of human being to the object, 
shows how much the object - the subject of the poem - means to the poet. The poem is a vector of drama, pathos, and surprise or rather suspense (the idea of the cliff-hanger, given the poem's title, is relevant): the emotion felt by the speaker on learning that the woman he thought loved him in fact loved another. The speaker of the poem begins by telling the cliff he will, standing (or sitting) on top of it, relate to it "a page from your history". One is reminded of Wordsworth's "There was a Boy" (composed in 1789) with its opening address to the cliffs: "There was a Boy; ye knew him well, ye cliffs /And islands of Winander!" Perhaps typically of each poet, Wordsworth's poem mourns the loss of childhood innocence and instinctive communion with Nature, whereas Hardy's turns out to be inspired by a love triangle: the woman beloved of the speaker - his wife, likely - revealed, when she and the speaker were once sitting "silent" and "listless" on the sea-cliff, that she was in love with another man, on board a ship (not taken here as an object) that sails past the sea-cliff's "jutting head" before the couple's eyes. The poem's first three stanzas are all explicitly addressed to, and mention, the sea-cliff, while the last one does not mention it, although the whole poem can be taken to be addressed to it. Two further objects, this time not personified or addressed, enter the poem in the last stanza, through a series of lines all dramatically run-on:

He slid apart

Who had thought her heart

His own, and not aboard

A bark, sea-bound...

That night they found

Between them lay a sword.

8 Hardy objectifies the woman's heart by placing it on board a ship. But the third object of the poem, the sword, is the most striking: the sword objectifies and makes concrete the now openly declared difference between the speaker and the woman he loves. The woman's revelatory declaration - or declarative revelation - brings about a transformation in the love relationship between the speaker and her, perhaps, indeed, transforming it into one of hate. The poem then brings all of its components, including its objects, into a transformative poetic force-field. The water of the sea, the "solid stone" of the sea-cliff, and the metal of the (metaphorical) sword: Hardy uses the objects, and the material of the objects, to get at something elemental in the quarrel between the speaker and his faithless wife. The elemental nature of the objects points, if only by contrast, to human frailty, as figured in the speaker of the poem's own broken heart.

\section{The object speaks}

Rather than addressing objects, other poems are themselves, in whole or in part, voiced by objects. In several different ways, Hardy exploits the technique of prosopopoeia which, for our purposes, is more than personification since it gives objects the power of speech. Such a device goes to the heart of Hardy's poetics and perhaps to the heart of the art of lyric poetry ${ }^{6}$. But in previous poems Hardy had used the device to personify Nature as a whole, or took objects in Nature, such as the "pool, /Field, flock, and lonely tree" in "Nature's Questioning" (Hardy 66-67), as metonymies by which to question Nature as a phenomenon, so that, as Allen Tate pointed out in relation to the poem, the objects themselves are unparticularised ${ }^{7}$. Tate in fact does argue that the objects are "weakly perceived" since their identity as themselves is not sufficiently established. In 
other words, they merely serve Hardy's own philosophical "questioning". It is interesting to note that such poems as "Nature's Questioning" and "To Outer Nature", among the main examples of Hardy's texts chosen by Nashimura and the critics he adduces (he also discusses Under the Greenwood Tree) are taken from Hardy's first poetry collection, Wessex Poems (1898). Hardy's writing of objects might then be perceived as part of a trajectory over the course of which he gradually moved from general statements and pathetic fallacy to a greater degree of particularisation and a warmer degree of appreciation both of the natural world and of the link between man and the latter. If this argument were possible, a late poem such as "Afterwards" would tend to bear it out. One of the reasons why this poem is so beloved a part of Hardy's poetic production is that it takes the objects as they are, and does particularise them (without calling upon any specific rhetorical device). Once in each of the poem's four stanzas, Hardy contents himself with the more discreet but repeated deictics and the intensifying adjective "such": "He was a man who used to notice such things"; "To him this must have been a familiar sight"; "such innocent creatures"; "He was one who had an eye for such mysteries"; "He...used to notice such things" (italics mine). Hardy and his poetics are at home with "such things", and perhaps "things" as such, because his sensibility takes pleasure in what Michael Edwards calls their "quiddity". Edwards writes that Hardy's "sensibility responds to the least thing seen or heard" (Edwards 214-215). Hardy is thus perhaps more satisfying as a poet when he leaves off his Wordsworthian "obstinate questionings/of sense and outward things" (from the "Immortality" ode ${ }^{8}$ ) and devotes his attention to realia as they are and in what they mean to him.

10 In Human Shows objects are observed for themselves, despite the theatrically-inflected title of the collection, without (necessarily) being part of a pathetic fallacy. The persona's voice in "Green Slates" (Hardy 712) as it were hands over to the eponymous objects in the last two lines of the poem ${ }^{10}$. But there are several objects in the poem, typical of the way in which Hardy concretises his thought through object-metaphors as well as describing what are intended to be realia. Hardy's use of the indeterminate term "A form" serves to objectify, or rather reify, the pictorial abstract figure of Emma against "the slate background" in Penbethy slate quarry in Cornwall where, in 1870, Hardy had gone, accompanied by Emma and her married elder sister Helen, to inspect the slate to be used for the restoration of St Juliot's Church for which Hardy had been commissioned. The poem commemorates then a partial crystallisation of Hardy's love for Emma "fifty years" (!) after the event. Emma's "form" is made even more abstract by the unusual diction and contorted syntax which works against natural word-order: the speaker saw "A form against the slate background there,/Of fairness eyecommanding.", Hardy splitting the noun group "Of fairness" from its antecedent, "A form", at the beginning of the previous line, so that at first the woman (in the next stanza we learn to what, or to whom, the "form" corresponds) seems to be a mere form, insisting on the form's beauty through the Miltonic inversion and the invention of the compound adjective, as though no already-existing adjective could do that beauty justice. The green slates themselves, physically and geographically detached - quarried - from their original site, serve as an objective correlative of Hardy's incipient love for the young woman:

Green slates - seen high on roofs, or lower

In waggon, truck, or lorry - 
Cry out: 'Our home was where you saw her

Standing in the quarry!'

11 (One notes incidentally an echo of Hardy's West Country accent, or ear, in the lower/ saw her rhyme, with the West Country "low" corresponding to RP "law"). However, as in other poems discussed here, it is the blend of objects as realia and as metaphors which is perhaps most outstanding, as in the phrase in the third stanza "strangepipped dice my hand has thrown me", in which current word order is again inversed, and the grammatical object - "dice" - placed before the verb. Hardy uses the object the dice - to offer a paradox: the speaker throws the dice himself ("my hand") and is thus in a sense responsible for the way in which the circumstances of his life have come about, "strange" or puzzling as they are, while the pips are the dots from one to six on each face of the dice and not in themselves "strange".

"The Sundial on a Wet Day" (Hardy 808-809) is spoken by the sundial. The latter in turn personifies the sun as "He", an almost godlike figure, rejoicing in the fact that, in spite of rain,

$$
\begin{aligned}
& \mathrm{He} \text { is still up there, } \\
& \text { And may gaze out } \\
& \text { Anywhen, anywhere; } \\
& \text { Not to help clockmen } \\
& \text { Quiz and compare, } \\
& \text { But in kindness to let me } \\
& \text { My trade declare. }
\end{aligned}
$$

The declarative ending hints at the poem as a cipher for the naturalness of a certain kind of poetic activity and for the latter's dependence on something other than itself in this case, the object (the sundial). There may be an Apollonian subtext to the poem, to the extent that Apollo was the god of both the sun and of poetry. The sundial - like the poet - finds its delight in exercising its "trade", its craft or (not-so-sullen) art. Hardy transforms the humble object, not known for its beauty, and hardly noticed or necessary in a time of mechanisation ("clock"), into an ars poetica. Furthermore, Hardy uses the unfamiliar technical term "gnomon" (the raindrops "down/My gnomon drain"), denoting the rod the shadow of which, falling on the face of the sundial, indicates the time. The term derives from the Greek verb gignosko, to know, and intimates an interpretation of the poetic art as one in which understanding and cognition guarantee any usefulness it may have. The object in the poem, or poems, then, carries weight within the process of cognition that is the poem, and the reading of the poem.

“The High-School Lawn" (Hardy 812) offers an even more subtle use of prosopopoeia:

Gray prinked with rose,

White tipped with blue,

Shoes with gay hose,

Sleeves of chrome hue;

Fluffed frills of white,

Dark bordered light;

Such shimmering through

Trees of emerald green are eyed

This afternoon, from the road outside.

They whirl around:

Many laughters run

With a cascade's sound;

Then a mere one. 


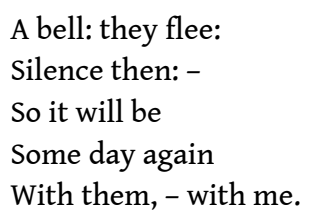

This is because only the last line confirms that the lawn itself voices the poem. The lawn is literally in a perfect position, indeed a privileged one, to relish sympathetically the sights and sounds of schoolchildren's afternoon play. The objects - clothes, shoes, colours - Hardy places in first position in the poem, with no main verb or subject of the main verb when it comes ("are eyed"), so that the action of the poem is concentrated in the objects which seem indeed endowed with a life of their own. Hardy provides a variation on this approach at the beginning of the last stanza in which, preceded by the article, the noun "A bell" suffices to conjure up the object's action and its sound. The pronoun "They" which appears in the seond and third stanzas takes on a certain ambiguity since it could either refer back to the objects (which would be a logical, grammatical deduction), or else stand for the schoolchildren. This exemplifies Hardy's general approach to objects in the poems: they are liable to be animated if not personified. The poem might make a possible contrast with Yeats's "Among School Children" which dates from the same period as Hardy's poem, having been composed in 1926. The elderly persona of Yeats's poem observes the children sitting in rows in their classrooms with their mistresses, doubtless holding their natural exuberance in check, though the poem does end with an ecstatic vision of dance. How typical of Hardy, though, to show the children in joyful motion under no watchful or censorious adult eye. Once again a dialectics of presence and absence underpins or, rather, in the case of "The High School Lawn", becomes the explicit subject of, the poem. The poem works on a temporal matrix of alternation and iteration ("So it will be...again"), perfectly mirrored in the alternate rhymes, metrical pattern, and stanzaic division. The poem is in dimetre except for the variation in the longer eighth and ninth lines which are tetrametrical. The unusual pluralisation of the noun "laughter" almost turns the laughter into a multiplicity of objects.

\section{"Bags of Meat": reversing the perspective}

Conversely to poems previously examined, the persona of "Bags of Meat" does not reify a living being (in the sense that Hardy sees the Emma of "Green Slates" as a mere "form", for instance). Rather, Hardy castigates the lack of empathy for animals which he finds within the farming trade - Hardy or, rather, his speaker, since the writer himself admitted he was not vegetarian ${ }^{11}$. He takes on the mantle of polemicist in this poem, just as his whole poetic oeuvre is an explicit - and sometimes explicit - rebuke to critics of his prose fiction. There is possibly a slight touch of irony or ambiguity to the poem since Hardy criticises the exploitation of animals for human consumption while espousing, not without relish, the "show" of the cattle auction, with its sense of theatre and ritual ${ }^{12}$. The theatrical side of the setting Hardy stresses through the word "scene" in the last stanza: the speaker imagines the animals reproaching the humans for bringing them to the "sinister scene" of the cattle market. This reinforces and dramatises the undoubted tragic element of the poem ${ }^{13}$.

The poem consists of a series of observations of the sale of animals at a cattle-market. Unusually for Hardy, he eschews regularity in the poem, be it in terms of metre, rhyme 
or number of lines per stanza. The first stanza is made up of eight lines; the second, six lines; the third, four; the fourth and fifth, eight lines; and the sixth, eleven lines. Hardy takes the poem-title from the words of the auctioneer presenting a steer at a cattlemarket: "Here's a fine bag of meat", words which Hardy quotes in slightly altered form as the first line of the poem, adding the plural and removing the adjective, and which transform the living animal proleptically into an inanimate object, the commercial end-product of its life. The auctioneer does not see the animal as a living being but as mere commodity: hence the poem is anti-bucolic, in keeping with Hardy's perspective on country life since Far from the Madding Crowd (1874), in which, over half a century before "Bags of Meat", he invented his own, Wessex, brand of anti-pastoral. "Bags of Meat" is a protest at the inhumane treatment of animals and ecological protest at the exploitation of the natural world for material gain, contrasting the jocular sales-talk of the auctioneers with the undignified treatment of the animals, and the latter's own feelings as the speaker imagines them. Hardy focuses in turn on a steer, a heifer, a bull, and a calf. The implication of the plural in the poem-title is that they will all be turned into bags of meat. In the last stanza, the speaker reverses the perspective, revealing the underside of a situation vaunted by the auctioneers for its glamour: the "young bull" is worth thirty pounds to "have his picter done". The glamour of the cattle market is precisely an example of the human show Hardy's title sets forth, except that the show here is more inhuman than human, and Hardy wants to expose what he calls in the last stanza its "sinister" side. This is but one of a series of adjectives in the last stanza designed to counter the sales talk about the animals and their mistreatment - the way in which they are "prodded" (first stanza), "rapped on the horns and snout" (fourth), struck "on the buttock" and branded (fifth). It is arguable that Hardy's view in the poem is Manichean, especially as he himself was not vegetarian. But poem's simple, fixed moral standpoint need not detract from the poem's power: quite the contrary, if anything. One might, in conclusion, compare this poem with a latterday "kin", "The Cows on Killing Day", by the Australian poet Les Murray (1938-2019) (Murray 125). Murray keeps Hardy's anthropomorphic premise but takes it a stage further by having the cows themselves voice the poem ${ }^{14}$, which they do through the object-pronoun "me" used throughout the poem as the subject-pronoun: "A stick goes out from the human / and cracks, like the whip. Me shivers and falls down / with the terrible, the blood of me, coming out behind an ear." Hardy's poem omits explicit representation of the slaughter but adumbrates it through the violence meted out to the beasts, including, as in Murray's poem, their being struck with a stick: the bull is "rapped on the horns and snout" while, concerning the calf, "The stick falls [...], /On the buttock of the creature sold". The last stanza of Hardy's poem stages an agonistic struggle between eros - the farmer keeping the beast on the land - and thanatos - the butcher: a struggle in which, this being Hardy ${ }^{15}$, "the butcher wins". After awarding the beasts both subjectivity and subject-status in the early part of the stanza - "Each beast [...] /Looks round at the ring of bidders there /With a much-amazed reproachful stare", the last words of the poem ("the butcher wins, and he's [sc. the beast's] driven from the place.") return the animal to its object-status announced in the poem-title and first line.

\section{"Another sphere"}

18 In order to reach a tentative conclusion, one might first take up one or two points made by Tim Ingold in his article "Bringing things to life: creative entanglements in a world 
of materials", in order to see whether they might the idea that Hardy is bringing to poetic life the things in his poems. A shift, then, operates here, from "objects" to "things". Ingold follows Heidegger by saying that an object "presents its congealed, outer surfaces for our inspection". This notion would seem to chime with that of "show" in Hardy's volume title: the show is the surface, whether it be of people or things. The adjective "congealed" adds to the negative connotation of the object within this perspective. Ingold continues: “The thing, by contrast, is a 'going on', or better, a place where several goings on become entwined [...] To observe a thing is not to be locked out but to be invited in to the gathering." An object becomes a thing when it is seen holistically, that is, as belonging within, and taking in, the broader, dynamic, transformative processes of life. Could this perspective be applied to the last poem in Human Shows, "Why Do I?"? And would it enable us the better to understand the role of objects - and things - in Hardy's poetry?

Why Do I?

Why do I go on doing these things?

Why not cease?

Is it that you are yet in this world of welterings And unease,

And that, while so, mechanic repetitions please?

When shall I leave off doing these things? -

When I hear

You have dropped your dusty cloak and taken you wondrous wings

To another sphere,

Where no pain is: Then shall I hush this dinning gear.

The poem gives no direct indication as to what the "things" that make up the speaker's repetition compulsion might be, any more than to whom the "you" refers. As with any fine poem, several readings are possible. The poem gives an impression of presence one might say, the poem presents, or presences itself - through the repetition of the deictics: these, this, these, this. The speaker seems to be questioning himself - thinking out loud, even - in the first two lines, and the first line of the second stanza. The dynamism of the poem is reflected not only in the metre, a combination of regularity and irregularity in the stress patterns and line lengths, but also in the poem's temporal features: "while" the first stanza anchors, but not freezes, poem, speaker and interlocutor in the present, the second is wholly proleptic. In fact, if there is a tension at work here, which there undoubtedly is, it is not the dialectical relationship between "past and present", but rather the dialectical dynamic between present and future which is by definition, to apply a spatial metaphor to rhetoric, forward-looking. At the same time, as the poem look to the future the questioning forms and tone of the first four sentences, all of which are questions, gives way to the long, four-line sentence that constitutes the answer to the question posed in the second stanza's first line. The sense of certainty the poem conveys is reinforced by the minimal number of rhymes, only three rhyme sounds ("ings", "ease", and "ear") for ten lines in all, perhaps designed to give a (willed) impression of monotony. The syntax is sufficiently varied, however, to counter or at least balance this impression, above all in the line which houses two named objects, the cloak and wings, the structure of which might indeed seem clumsy, though it could just as well be delicate, making the reader (this reader, at least) pause for a second, to notice that "have" does double duty both for "dropped" and "taken", and that the subject of the verb "have taken" is not "you" but "wondrous wings". It is the presence of the "you", the anonymous addressee, who could be a, or the, Muse 
(depicted, by Ovid for example, as winged), or a current love or a past one, that, according to the argument of the poem, keeps the poet "doing these things". As Tim Armstrong writes: "Demonstrative pronouns and adjectives which normally have a clear referent - 'then', 'the thing that I did', 'one who's there' - come unlocated and mysterious [...]" (Armstrong 328) The only objects, as one usually understands the word, are the "cloak" and "wings" which are relatively unproblematic, although generically different from each other, and clearly intended to be. This leaves the meaning of "these things" undecided. Even so, the adjective "wondrous" acts as an expression of wonder which attends the positive dimension of Hardy's lyric achievement, and indeed Gitting calls the poetry-writing of Hardy's old age a "miracle" (Gittings 274). Given that the demonstrative could refer to what the speaker is currently concerned with, the "things" in question are arguably the poems Hardy is currently working on. Independently of the quality of the poems themselves, there is a heroism in the act of writing them, in Hardy, the craftsman, the journeyman till the end, expending himself, every morning at his writing desk, in the task at hand, in the work he knew: "He allows nothing to interfere with his morning's work", Florence Hardy wrote (255); "Lyrics still poured from him, some of them as moving and accomplished as anything he had written in all his long life" (274). What Gittings calls Hardy's "lyrics" could be the "things" Hardy does here: the enduring, disciplined writing of them. Hence, poems are done as well as made, since they involve willed activity, if only (if such is the case) the physical committing of them to paper and print. Although poems can, especially since Zukovsky and the Objectivists, be considered as objects, it is perhaps more fruitful to consider them, in Hardy's case, as things such as Ingold's perspective takes the latter to be: phenomena involved in setting, time and process. Harder to interpret satisfactorily are the "mechanic repetitions", which seem to refer back to "these things" and forward to "dinning gear", all of which are linked by the demonstratives and seem to refer to the same phenomena. "Mechanic repetitions" might refer to the principles of metre and rhyme which are, by definition, repetitive. They need not be mechanical, but they might be habitual, and Hardy may be pointing to his lifelong habit of verse-writing which invariably respects these principles. "Gear" would echo the adjective "mechanic" while "dinning", more dynamic an adjective than "mechanic", can only denote sound: Hardy is saying that his poems, though some have musical titles, are not mellifluous, an idea borne out by the fact that Human Shows is the collection of Hardy's in which the Latin term "concordia discors" appears ${ }^{16}$. The spectre or Muse figure represented by "you" literally compels the speaker to keep writing, producing the "things" (the dynamic, processing objects) that are his poems which do, after all, "please ${ }^{17}$ ". His writing is thus compulsive, with the risk, according to a negatively-connoted reading, of transforming the poet himself into an automat, and therefore an object. His writing is thus compulsive, the presence of, and wonder induced by, "you", keeping the poet in a permanent state of dynamism and creation and, yes, pleasure. 


\section{BIBLIOGRAPHY}

Armstrong, Tim, “Thomas Hardy", in A Companion to Modernist Poetry, eds. David E. Chinitz \& Gail McDonald, Oxford: Blackwell, 2014, 325-334.

Björk, Lennart (ed.), The Literary Notebooks of Thomas Hardy, Volume 2, Basingstoke: Macmillan, 1985.

Alexander, Michael, "Hardy Among the Poets", in Thomas Hardy After Fifty Years, ed. Lance St John Butler, London \& Basingstoke: Macmillan, 1977, 49-63.

Edwards, Michael, “The Transcendence of Things Seen”, in Thomas Hardy, Poet: New Perspectives, eds. Adrian Grafe \& Laurence Estanove, Jefferson, North Carolina: McFarland, 2015, 207-216.

Elliott, Ralph W.V., Thomas Hardy's English, Oxford: Blackwell, 1984.

Gittings, Robert, The Older Hardy (1978), London: Penguin, 1980.

Hardy, Thomas, The Complete Poems, ed. James Gibson, Basingstoke: Palgrave, 2001.

Ingold, Tim, "Bringing Things to Life: Creative Entanglements in a World of Materials", NCRM

Working Papers Series 5/1 (July 2010), http://eprints.ncrm.ac.uk/

1306/1/0510_creative_entanglements.pdf (last accessed 23 Sept 2019).

Keats, John, Selected Poems and Letters, eds. Robert Gittings \& Sandra Anstey, Oxford: Heinemann, 1995.

Morgan, Rosemarie, Student Companion to Thomas Hardy, Westport, Connecticut; London: Greenwood Press, 2007.

Murray, Les, New Selected Poems, New York: Farrar, Straus \& Giroux, 2012.

Nishimura, Satushi, "Thomas Hardy and the Language of the Inanimate", Studies in English Literature, 1500-1900 43.4 (Autumn, 2003): 897-912.

Trotter, David, “On the Nail: Functional Objects in Thomas Hardy's The Woodlanders", in Literary Bric-à-Brac and the Victorians: From Commodities to Oddities, eds. Jonathan Shears, Jen Harrison, Farnham: Ashgate, 2013, 115-128.

West, Anna, Hardy and Animals, Cambridge: Cambridge University Press, 2017.

Winnicott, D. W., “A Study of the First Not-Me Possession”, Collected Works, Volume 5 1955-1959, eds. Lesley Caldwell \& Helen Taylor Robinson, Oxford: OUP, 2016, 406-420.

Wood, James, “Anxious Pleasures”, London Review of Books 29.1 (4 January 2007): 25-29, https:// www.lrb.co.uk/v29/n01/james-wood/anxious-pleasures (last accessed 23 Sep 2019).

\section{NOTES}

1. Not the least interesting aspect of Human Shows, the volume of Hardy's verse on which this article concentrates, is the fact that it contains poems such as "The Prospect" and "When Oats were Reaped" which were explicitly dated, beneath the text, respectively 1912 and 1913, though it is unclear whether or not such postscripts indicate the date of composition or an emotional throwback to those years. 
2. Tim Armstrong's excellent article "Thomas Hardy" in The Blackwell Companion to Modernist Poetry (2014) focuses on Human Shows in order to argue that various facets of the volume and the poems in it play into Modernist poetics.

3. See James Wood who calls Hardy a writer of "animistic" feeling.

4. The possible application of Winnicott's theories to Hardy's treatment of objects would warrant a separate study in itself.

5. "the impression left by the book is thin." (Gittings, 268)

6. As J. Hillis Miller has argued: "Without prosopopoeia no poetry." (quoted in Nishimura 899).

7. Tate quoted in Nishimura (904).

8. In his "Apology" to Late Lyrics the poetry collection that preceded Human Shows, Hardy rejected the "disallowance of 'obstinate questionings' and 'blank misgivings"' in poetry, without, incidentally, attributing the two phrases in quotation marks to their author. He thus defended the philosophical dimension of his poetry which seems less prevalent in Human Shows, a collection for which for which he wrote no preface. He perhaps expected the somewhat lengthy full collection-title to suffice by way of description or justification.

9. Robert Gittings' unsurpassed biography of the poet shows how, around the time Hardy was composing the Human Shows volume, he was also involved in writing his Famous Tragedy of the Queen of Cornwall, and taking a close interest in adaptations of various novels of his for the stage (see Gittings 255-269).

10. Another possible example of this technique is "Inscriptions for a Peal of Eight Bells (After a Restoration)", a poem which is both occasional verse and indeed fairly trifling. Each of the bells voices a stanza of the poem.

11. Hardy told Alfred Noyes that he was in this respect "not consistent". See West $131 \mathrm{n} 4$. Hardy says this in a "dismal" tone.

12. See, for example, the well-known scene at the farmers' market in Chapter XII of Far from the Madding Crowd.

13. As Ralph Elliott points out, Hardy commonly uses the word "scene", nor is the use of theatrical imagery is unique to him. Among other contexts, Elliott quotes from "An August Midnight" (1899) ("this scene"). Even at this relatively early stage in his poetic career, and despite the speaker's need to draw a philosophical conclusion from the insects' presence around his writer's lamp, and the awkward inversion and chiasmic diction - in the last line, the insects the poem celebrates are said by the speaker to "know Earth-secrets that know not I" -, Hardy's fellow-feeling for the animals is the same as in "Bags of Meat". See Elliott 158.

14. In a different vein, Hardy did adopt this technique for "Why She Moved House (The Dog Muses)" also in Human Shows.

15. The remark is not quite fair: in the same collection, if other, agricultural animals are "consigned to doom" like the sheep in "A Sheep-Fair", the sparrow and cat both survive in "Snow in the Suburbs", the latter thanks to human intervention.

16. In "Genetrix Laesa".

17. A further study would contrast the commonplace idea that repetition in music and poetry are sources of pleasure with the Freudian one that in repetition compulsion the subject re-enacts specifically painful events from the past: this perspective could be applied to much of Hardy's poetry. "Why Do I?" perhaps owes its specific character to the encounter between these two notions. 


\section{ABSTRACTS}

How does Hardy represent objects in his poetry? What function(s) do they perform? Hardy uses the technique of personification but goes well beyond it. Thus "To a Sea-Cliff" begins as an address to place which finally has everything to do with drama and nothing to do with Nature as such. "The High-School Lawn" and "Green Slates" show Hardy lending objects voice, but the point of the poems lies not in rhetorical technique itself but in broader poetic creation, the recreation of emotion, and the evocation of deep time. Hardy anthropomorphises the animal kingdom in such a way as to suggest that the killing of sentient beings for human consumption, transforming them into "Bags of Meat", is an ecological tragedy. These poems show the later Hardy as philosophical a poet as ever, an empirical one grounding his poetics, not merely in the object itself, but in what the object points to, and as an analogue for the realia of experience. If this argument were valid, it would add another dimension to the appreciation of Hardy's thought, complementing the more familiar one highlighting his disillusion. The last poem in the collection, "Why Do I?", leads us to conclude with a reflection inspired by Tim Ingold's differentiation between objects and things: the poem is a weird, spectral ars poetica in which the "things" the persona says he "does" are actually, in the absence of any (other) referent, the poems that make up the collection and the activities that form the writing process.

Comment Hardy représente-t-il les objets dans sa poésie, et surtout dans le recueil Human Shows (1925) ? Quelle(s) fonction(s) remplissent-ils ? Hardy utilise la technique de personnification mais va bien au-delà. Ainsi, « To a-Sea-Cliff » commence comme une apostrophe qui a finalement tout à voir avec le drame et rien à voir avec la nature en tant que telle. "The High-School Lawn » et «Green Slates» donnent voix aux objets, mais l'intérêt des poèmes ne réside pas dans la technique rhétorique elle-même, mais dans une création poétique plus large, la recréation de l'émotion et l'évocation du «temps profond». Hardy anthropomorphise le règne animal de manière à suggérer que le fait de tuer des êtres sensibles pour la consommation humaine, en les transformant en "Sacs de viande », est une tragédie écologique. Ces poèmes montrent le Hardy de ses dernières années comme un poète toujours aussi philosophique, empirique, fondant sa poétique non seulement sur l'objet lui-même, mais sur ce que cet objet désigne et en tant qu'analogue de la réalité de l'expérience humaine. Si cet argument était valable, il ajouterait une autre dimension à l'appréciation de la pensée de Hardy, complétant celle, plus familière, qui met en avant son pessimisme. Le dernier poème du recueil, « Why Do I? ", nous amène à conclure par une réflexion inspirée par la différenciation qu'effectue Tim Ingold entre objets et choses : ce poème est un étrange ars poetica spectral dans lequel les « choses » que le personnage dit "faire » sont en réalité, en l'absence de tout (autre) référent, les poèmes qui forment le recueil ainsi que les activités que comporte le processus d'écriture.

\section{INDEX}

Mots-clés: objet, prosopopée, interprétation, post-romantisme, realia, Nature, émerveillement, corrélat objectif, chose

Keywords: object, prosopopoeia, interpretation, post-Romanticism, realia, Nature, wonder, objective correlative, thing

oeuvrecitee Human Shows, To a Sea-Cliff, Green Slates, Sundial on a Wet Day (The), High-School Lawn (The), Bags of Meat, Why Do I? 


\section{AUTHOR}

\section{ADRIAN GRAFE}

Adrian Grafe is Professor of Literature in English at Université d'Artois. He co-organised the 2012 Thomas Hardy Poetry Conference with Emilie Loriaux at Artois, and co-edited Thomas Hardy, Poet: New Perspectives with Laurence Estanove (McFarland, 2015). He has published broadly on poetry in Britain, France, America and elsewhere. He is a Corresponding Fellow of the English Association, and Book Reviews Co-Editor, with Emily Taylor Merriman, of the Hopkins Quarterly. Along with poetry, he also researches popular music. 